\title{
Studies on the heat and disinfectant resistance of a spore-forming spoilage bacterium
}

\author{
G. Kiskó* \\ e-mail: kisko.gabriella@etk.szie.hu
}

\section{A. Taczmann-Brückner*}

e-mail: bruckner.andrea@etk.szie.hu
N. Hladicekova*

e-mail: hldck.nataly@gmail.com

\author{
Cs. Mohácsi-Farkas*
}

e-mail: farkas.csilla@etk.szie.hu

*Szent István University, Faculty of Food Science, Department of Microbiology and Biotechnology, H-1118 Budapest, Somlói út 14-16.

\begin{abstract}
Heat resistant thermophilic spore-forming bacteria, such as Aeribacillus (A.) pallidus, may contaminate the surfaces in food facilities resulting food spoilage of the products. The aim of this work was to determine the heat and disinfectant resistance of an A. pallidus strain that was isolated from a canning factory environment. Compared to other heat-resistant spore-forming bacteria, it did not prove to be very resistant to heat with a $\mathrm{D}_{10}$-values of $A$. pallidus from 12.2 min to 2.4 min $\left(\right.$ at $102{ }^{\circ} \mathrm{C}$ and at $\left.110{ }^{\circ} \mathrm{C}\right)$, with a calculated z-value of $11.6^{\circ} \mathrm{C}$. Not only spores but vegetative cells showed resistance against all investigated disinfectants.
\end{abstract}

\section{Introduction}

Thermophilic, endospore-forming bacteria can cause serious problems in different fields of food industry by their ability to form resistant spores and

Keywords and phrases: Aeribacillus pallidus, heat resistant spores, disinfection, food spoilage 
biofilms (Flint et al., 2001; Kilic et al., 2017). Endospores of bacteria are able to survive extreme environmental conditions. They are highly resistant to preservation techniques, e.g. to heat treatment, drying, irradiation, pressure treatment, or chemicals. Thermophilic bacteria are able to grow at 70 ${ }^{\circ} \mathrm{C}$. The first research about their characterization was performed by Miquel in 1888. Since then, many strains of thermophilic bacteria belonging to the Bacillus and Clostridium genera have been characterized (Maugeri et al., 2001; Belduz et al., 2003). Recently, several bacteria of Bacillus genus have been reclassified, such as Alicyclobacillus, Paenibacillus, Brevibacillus, Aneuribacillus, Virgibacillus, Salibacillus, Gracilibacillus, Ureibacillus, and finally Geobacillus. Thermophilic bacteria in the 1 . and 5 . genetic groups were classified into the Geobacillus genus (Iida et al., 2005).

Thermophilic bacteria have an optimal growth temperature range between 45 and $70{ }^{\circ} \mathrm{C}$, wherefore they are isolated from hot environments such as hot springs, geothermally heated soils, shallow marine hot springs, petroleum reservoirs, deep-sea hydrothermal vents, the leachate of a waste pile from a canning factory, hot water pipelines, heat exchangers, waste treatment plants, etc. (Rahman et al., 2004; Bae et al., 2005). Microbial spoilage contributes to the vast amount of food that is wasted and the associated financial losses. Spoilage of heat-treated food products are usually provoked by spore-forming bacteria as a result of the resistance of spores to high temperatures commonly used to preserve foods. Canned food products generally undergo spoilage by thermophilic bacilli. Denny (1981) had demonstrated that thermophilic bacteria were the prime cause of spoilage of canned corn. Spoilage of heat-treated dairy products is often caused by thermophilic spore-formers. It was demonstrated by Scheldeman and co-workers (2006) that spoilage spore-formers, e.g. Bacillus licheniformis and Aeribacillus pallidus, were most frequently isolated from farms and may cause spoilage of treated milk.

In recent years, there has been evidence of contamination of canned food (especially canned corn) products by new spore-forming, thermophilic bacteria from the genus Aeribacillus (previously Geobacillus). Members of the genus Aeribacillus are aerobic, thermophilic, alkalitolerant, motile, and Grampositive rods $(0.8-0.962-5 \mathrm{~nm})$ that occur singly, in pairs, or in chains. The reason for the spoilage of ready canned corn by $A$. pallidus can be the improper performance of thermal processes due to the incorrect relation between heating time and temperature. For that reason, investigation of the heat resistance of A. pallidus spores and determination of decimal reduction time (D-value) are high concerns for the canning industry. In comparison with other thermophilic bacteria from the genus Geobacillus, there are no reported D-value data for 
A. pallidus in canned corn products.

Therefore, the aim of this study was to determine the influence of heat treatment and sanitizers on the survival of spores of Aeribacillus pallidus.

\section{Materials and methods}

\subsection{Bacterial strain}

In this study, Aeribacillus pallidus T6 3 (NCAIM B.01143) culture was used. The strain was isolated from spoiled canned corn products. Isolation and storage of A. pallidus culture was done using Casein-peptone Soymeal-peptone Agar (CASO agar, Merck).

\subsection{Preparation of spore suspensions}

Agar slants of $A$. pallidus cells were flooded with sterile distilled water, and then $2 \mathrm{ml}$ of suspension was transferred on the surface of CASO agar in 200mm-diameter Petri dishes.

Inoculated Petri plates were incubated at $55^{\circ} \mathrm{C}$ for 48 hours and then were transferred to a refrigerator and stored at $15^{\circ} \mathrm{C}$ for 72 hours. Spores then were collected by scrapping the surface of the agar with sterile metal spatula, suspended in sterile distilled water, and washed three times by centrifugation $(4,000 \times \mathrm{g}$ for 10 minutes $)$. Spore suspensions were stored at $4{ }^{\circ} \mathrm{C}$ until they were used. The number of spores in a suspension was determined by the pour-plate method, and it was $8 \times 10^{9} \mathrm{CFU} / \mathrm{ml}$. Suspensions were diluted to obtain approximately $8 \times 10^{7} \mathrm{CFU} / \mathrm{ml}$. Activation of spores was done by heating spore suspension in water bath at $80^{\circ} \mathrm{C}$ for 10 minutes.

\subsection{Heat treatment analysis}

Canned corn brine $(\mathrm{pH} 6.11 \pm 0.18)$ was used as a heating medium. Heating experiments were carried out in small glass vials. After filling them with 2.5 $\mathrm{ml}$ of spore suspension, vials were sealed with gas burner flame. Thermal inactivation was performed in temperature-controlled oil bath (Memmert, Model ONE 7, Germany). The samples were heated in the oil bath at temperatures of $102^{\circ} \mathrm{C}, 104^{\circ} \mathrm{C}$, and $110^{\circ} \mathrm{C}$. The sample temperature was monitored continuously using Testo 110-1 channel NTC Thermometer with needle-type sensor. Triplicate samples were removed from the bath every 2 minutes, at 0, 2, 4, 6, and 8 minutes. After removal, the samples were immediately immersed into 
cold water. The viable spores were counted by triplicate plating on CASO agar and incubated at $50^{\circ} \mathrm{C}$ for 2 days.

\subsection{Calculation of D10-values}

$D_{10}$-values were calculated using the average slope $\left(D_{10}=-1 /\right.$ slope $)$ for each temperature treatment.

\subsection{Disinfection efficacy test}

\subsubsection{Disinfection test against vegetative cells}

A. pallidus was inoculated on CASO agar and incubated at $50{ }^{\circ} \mathrm{C}$ for 24 hours. The turbidity of the culture was set to OD 1 (the initial cell count was $3.2 \times 107$ $\mathrm{CFU} / \mathrm{ml}$ ). $400 \mu \mathrm{l}$ of corn brine was applied to clean, pre-sterilized stainless steel coupon surfaces, and be distributed evenly throughout the coupons $(8 \times 6$ $\mathrm{cm})$. The brine was dried on the surface in a laminar box, and $400 \mu \mathrm{l}$ of cell suspension $\left(10^{7}\right.$ cell $\left./ \mathrm{ml}\right)$ was uniformly dispersed on the surfaces and dried in a laminar box. $400 \mu \mathrm{l}$ of disinfectant suspension was applied to the surfaces, and cells were removed from the surface with a swab soaked in an inactivating solution after the time of exposure (Table 1).

Table 1: Recommended parameters for the industrial application of disinfectants

\begin{tabular}{lccc}
\hline Name & Concentration & $\begin{array}{c}\text { Contact time } \\
(\mathbf{m i n})\end{array}$ & $\begin{array}{c}\text { Temperature } \\
\left({ }^{\circ} \mathbf{C}\right)\end{array}$ \\
\hline Apesin DSR & $0.5 \%$ & 30 & 25 \\
Chlor-sept & $1: 10$ & 1 & 25 \\
Descosal & $1 \%$ & 30 & $25-30$ \\
Idro 86 & $3-5 \%$ & rinse as desired & \\
Innofluid-MF-M & $2 \%$ (generally) & $5-30$ & $35-50$ \\
& $8 \%$ (egg-contaminated surfaces) & & \\
Megabrite & $1-2 \%$ (generally) & $10-30$ & $30-80$ \\
& $5-20 \%$ (heavy contamination) & $15-60$ & $30-80$ \\
Rimadet-SR-310 & $3-5 \%$ & 20 & 25 \\
Wunder & $1: 10$ & 10 & $25-30$ \\
\hline
\end{tabular}

The surviving cells recovered by the swab were placed in an inactivating solution (1.56 g sodium thiosulfate $\left(\mathrm{Na}_{2} \mathrm{~S}_{2} \mathrm{O}_{2} \cdot 5 \mathrm{H}_{2} \mathrm{O}\right), 0.07 \mathrm{~g}$ of lecithin, $0.1 \mathrm{~mL}$ Tween $80 / 100 \mathrm{~mL}$ PBS) and vortexed. After serial dilution, the number of surviving cells was determined by plate counting on CASO agar. Incubation 
was carried out at $55^{\circ} \mathrm{C}$ for $24-48$ hours. As a control, clean brine-free surfaces were applied with the same procedure.

\subsubsection{Disinfection test against spores}

A. pallidus spores were heat-activated before disinfection test (10 minutes at $80^{\circ} \mathrm{C}$ ). Inoculation and treatment of spore suspension was carried out similarly as described in 2.5.1.

\section{Results and discussion}

\subsection{The heat resistance of Aeribacillus pallidus spores}

Thermal inactivation tests of $A$. pallidus spores at three different temperatures $\left(102^{\circ} \mathrm{C}, 104^{\circ} \mathrm{C}\right.$, and $\left.110^{\circ} \mathrm{C}\right)$ in corn brine have been performed. Decimal reduction times ( $\mathrm{D}_{10}$-values) were calculated by linear regression analysis $\left(\mathrm{D}_{10}=-1\right.$ /slope of a plot of log surviving cells versus time). Survival curves of $A$. pallidus spores at different temperatures are shown in Figure 1.

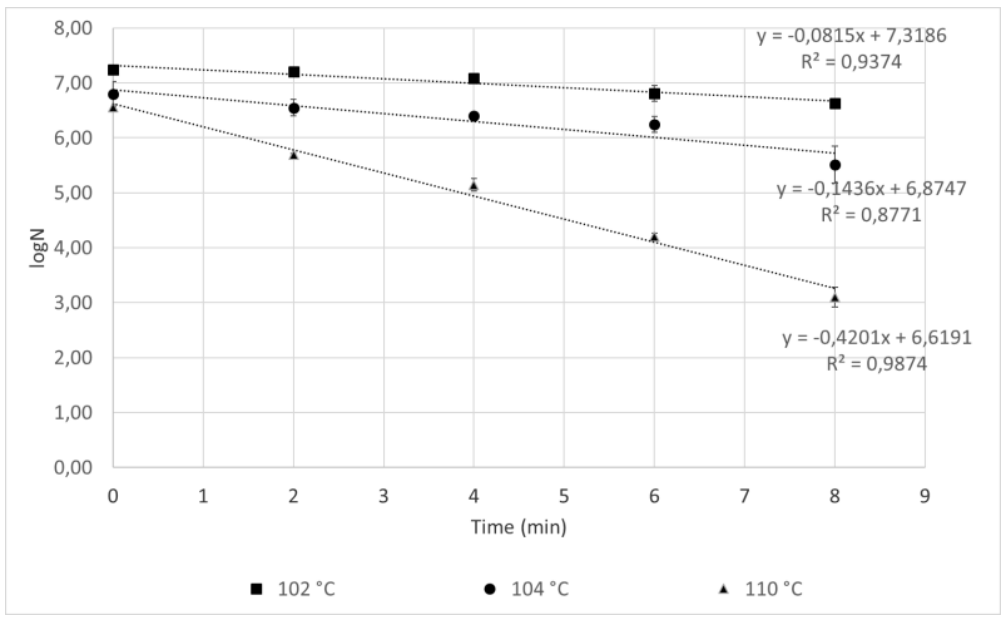

Figure 1: Survival curves of Aeribacillus pallidus spores in corn brine at different temperatures

Table 2 summarizes the D-values obtained at different heating temperatures in corn brine.

The D-values of A. pallidus ranged from 12.2 to $2.4 \min \left(\right.$ at $102{ }^{\circ} \mathrm{C}$ and at $110^{\circ} \mathrm{C}$ ), and the calculated z-value of the test strain was $11.6^{\circ} \mathrm{C}$. 
Table 2: $\mathrm{D}_{10}$-values of Aeribacillus pallidus spores at different temperatures in corn brine

\begin{tabular}{cc}
\hline Heating temperature $\left({ }^{\circ} \mathbf{C}\right)$ & D10-values (min) \\
\hline 102 & 12.2 \\
104 & 7.1 \\
110 & 2.4 \\
\hline
\end{tabular}

In comparison with literature data, the $A$. pallidus strain proved to be not extreme heat resistant in corn brine. Geobacillus stearothermophilus, a thermophilic spore-forming bacterium, has a D-value of $62.04 \mathrm{~min}$ at $112.8^{\circ} \mathrm{C}$, 18.0 min at $115.6^{\circ} \mathrm{C}$, and $3.33 \mathrm{~min}$ at $121.1^{\circ} \mathrm{C}$ in aqueous suspension, with a z-value of $8.3^{\circ} \mathrm{C}$ (Feeherry et al., 1987).

Warth (1978), when examining the heat tolerance and optimal growth temperature of Bacillus species, found that there is a relationship between optimal growth temperature and heat resistance. The composition of the culture medium has no effect on maximum growth temperature. However, the composition of the heat treatment medium ( $\mathrm{pH}$, water activity, etc.) greatly influences bacterial heat tolerance. Lopez et al. (1996) showed that the heat tolerance of $B$. stearothermophilus spores was reduced by 7 to 23 times when the $\mathrm{pH}$ of the heat treatment medium was lowered from 7 to 4 .

\subsection{Disinfection efficacy tests}

\subsubsection{Efficacy of different disinfectants against $A$. pallidus vegetative cells}

The metal coupons used in surface tests were designed to model the surface of industrial production lines, both in the form of clean and organic soilcontaminated surfaces.

Table 3 shows the extent of disinfectant-induced decrease in the number of cells between the initial cell count and the number of cells recovered after plating.

In general, disinfection treatment resulted in a mean 2.9 log reduction.

Against vegetative Aeribacillus pallidus cells, the most effective agents were Chlor-sept, Innofluid-MF-M, and Megabrite.

Chlor-sept disinfectant was examined at the specified concentration and at two end contact times (1 min, $30 \mathrm{~min}$ ) as per the manufacturer's instruction. 
Table 3: Cell count reduction of $A$. pallidus vegetative cells during disinfectant treatments

\begin{tabular}{lcccc}
\hline \multicolumn{2}{c}{ Disinfectant } & \multicolumn{2}{c}{ Reduction (Log N) } \\
\hline Name & $\begin{array}{c}\text { Used } \\
\text { concentration } \\
(\mathbf{( \% )}\end{array}$ & $\begin{array}{c}\text { Contact } \\
\text { time } \\
(\mathbf{m i n})\end{array}$ & $\begin{array}{c}\text { Clean } \\
\text { surface }\end{array}$ & $\begin{array}{c}\text { Surface } \\
\text { with } \\
\text { brine }\end{array}$ \\
\hline Apesin & 0.5 & 30 & 2.37 & 2.37 \\
Chlor-sept & 10 & 1 & 2.32 & 2.01 \\
& & 30 & 3.73 & 3.36 \\
Descosal & 1 & 30 & 2.43 & 2.20 \\
Idro-86 & 5 & 15 & 2.47 & 2.74 \\
Innofluid-MF-M & 2 & 10 & 2.47 & 2.32 \\
& 8 & 5 & 3.51 & 3.3 \\
Megabrite & 2 & 10 & 3.46 & 3.39 \\
Rimadet & 3 & 20 & 2.7 & 0.54 \\
Wunder & 10 & 10 & 3.01 & 2.84 \\
\hline
\end{tabular}

For Innofluid, using the two concentrations $(2 \%, 8 \%)$ given by the manufacturer, $8 \%$ treatment with only 5 minutes exposure time was more effective than 10 minutes contact time with $2 \%$ concentration. Megabrite has been shown to be effective at $2 \%$ concentrations for 10 minutes. The acidic detergent, Wunder, caused a reduction of 3 orders of magnitude in $10 \%$ concentration. The Rimadet chemical (3\%) on clean surface resulted a considerable cell count reduction in contrast with the organic-loaded surface, which showed the lowest efficiency. In the case of Apesin, the agent showed very low activity against the test strain, with no difference between the clean and soiled surfaces. Descosal (1\%) also had low efficacy, similarly to the previous agent, after 30 minutes of exposure. In the case of Idro-86, however, unexpected results were observed. After disinfection treatment, the number of surviving cells was higher on the clean surface than on the brine-containing surface.

Overall, the number of cells decreased several orders of magnitude; however, the lethal effect of the chemicals on the vegetative form of bacteria was not remarkable. The high survival rate is partly due to the presence of spores in the cell mass produced during vegetative cell culturing (the initial cell suspension showed the presence of spores after spore stain; results are not shown).

\subsubsection{Efficacy of different disinfectants against $A$. pallidus spores}

The results of the disinfectant test against spores are summarized in Table 4.

In the number of spores, $2-3 \log$ reduction was observed generally after treatment. The greatest reduction was caused by the chlorine-containing Chlor-sept 
as well as by Innofluid and Megabrite. Among them, the most effective one was the application of $10 \%$ Chlor-sept solution for 30 minutes - both on clean and organic soiled surfaces. Surprisingly, despite the efficacy of Innofluid, increasing the exposure time did not affect further the decrease in spore count. Megabrite was as effective against spores as against vegetative cells after only $2 \%$ treatment for 20 minutes.

In the case of Idro-86, a small but measurable difference could be observed between the results of the two surfaces. At 10\% concentration, Wunder resulted a moderate reduction in cell number on a clean surface, while the surface exposed to organic matter showed less efficiency. Rimadet was the least efficient at $3 \%$ concentration on both clean and dirty surfaces. In the applied concentration, Descosal and Apesin were moderately effective against spores.

Table 4: Spore count reduction of $A$. pallidus during disinfectant treatments

\begin{tabular}{lcccc}
\hline & Disinfectant & \multicolumn{2}{c}{ Reduction (Log N) } \\
\hline Name & $\begin{array}{c}\text { Used } \\
\text { concentration } \\
(\mathbf{\%})\end{array}$ & $\begin{array}{c}\text { Contact } \\
\text { time } \\
(\mathbf{m i n})\end{array}$ & $\begin{array}{c}\text { Clean } \\
\text { surface }\end{array}$ & $\begin{array}{c}\text { Surface } \\
\text { with } \\
\text { brine }\end{array}$ \\
\hline Apesin & 0.5 & 30 & 3.06 & 2.68 \\
Chlor-sept & 10 & 1 & 2.44 & 1.51 \\
& & 10 & 2.62 & 2.25 \\
Descosal & 1 & 30 & 3.52 & 3.3 \\
Idro-86 & 5 & 30 & 2.40 & 2.28 \\
Innofluid-MF-M & 8 & 15 & 2.65 & 2.73 \\
& & 5 & 2.89 & 2.87 \\
Megabrite & 2 & 10 & 2.98 & 2.93 \\
Rimadet & 5 & 20 & 3.20 & 3.10 \\
Wunder & 10 & 20 & 1.78 & 1.59 \\
& & 10 & 3.15 & 2.62 \\
\hline
\end{tabular}

Compared with other literature data, a similarly low spore count reduction was observed by Guan and co-workers (2013) for the heat resistant sporeforming bacterium Geobacillus stearothermophilus. Disinfectants reduced the spore counts on heavy-organic-load-containing surfaces by only less than 2 $\log _{10}$ within 2 hours of exposure.

In most cases, resistance decreased with increasing concentration, but increasing exposure time did not cause significant changes in either vegetative cells or spores. As expected, endospores proved to be more resistant to the vegetative form although the degree of resistance was not considerable. 


\section{Conclusions}

Because of the adhesive characteristics of spore-forming bacteria, they are ubiquitous in the food industry, in raw materials, ingredients, packaging materials, environment, and processing lines. Therefore, the contamination of end-products can easily occur. Due to their heat resistance, commonly used pasteurization processes fail to kill spores. Moreover, heat resistance may vary within the strains of a species and may differ according to the physiological state of cells and the composition of the food product (e.g. composition, $a_{w}$, $\mathrm{pH})$. Therefore, further research is needed to determine the resistance properties of spoilage spore-formers.

\section{References}

[1] S. S. Bae, J. H. Lee, S. J. Kim, Bacillus alveayuensis sp. nov., a thermophilic bacterium isolated from deep-sea sediments of the Ayu Trough. International Journal of Systematic and Evolutionary Microbiology, 55 . (2005) 1211-1215.

[2] A. O. Belduz, S. Dulger, Z. Demirbag, Anoxybacillus gonensis sp. nov., a moderately thermophilic, xylose-utilizing, endospore-forming bacterium. International Journal of Systematic and Evolutionary Microbiology, 53. (2003) 1315-1320.

[3] C. B. Denny, Thermophilic organisms involved in food spoilage: Introduction. Journal of Food Protection, 44. (1981) 144-145.

[4] F. E. Feeherry, D. T. Munsey, D. B. Rowley, Thermal inactivation and injury of Bacillus stearothermophilus spores. Applied and Environmental Microbiology, 53. 2. (1987) 365-370.

[5] S. Flint, J. Palmer, K. Bloemen, J. Brooks, R. Crawford, The growth of Bacillus stearothermophilus on stainless steel. Journal of Applied Microbiology, 90. (2001) 151-157.

[6] J. Guan, M. Chan, B. W. Brooks, L. Rohonczy, Influence of temperature and organic load on chemical disinfection of Geobacillus steareothermophilus spores, a surrogate for Bacillus anthracis. Canadian Journal of Veterinary Research, 77. (2013) 100-104. 
[7] K. Iida et al., Paenibacillus motobuensis sp. nov., isolated from a composting machine utilizing soil from Motobu-town, Okinawa, Japan. International Journal of Systematic and Evolutionary Microbiology, 55. (2005) 1811-1816.

[8] T. Kilic et al., Biofilm characteristics and evaluation of the sanitation procedures of thermophilic Aeribacillus pallidus E334 biofilms. Biofouling, 33. 4. (2017) 352-367.

[9] M. López, I. González, S. Condón, A. Bernardo, Effect of pH heating medium on the thermal resistance of Bacillus stearothermophilus spores. International Journal of Food Microbiology, 28. (1996) 405-410.

[10] T. L. Maugeri, C. Gugliandolo, D. Caccamo, E. Stackebrandt, A polyphasic taxonomic study of thermophilic bacilli from shallow, marine vents. Systematic and Applied Microbiology, 24. (2001) 572-587.

[11] T. J. Rahman, R. Marchant, I. M. Banat, Distribution and molecular investigation of highly thermophilic bacteria associated with cool soil environments. Biochemical Society Transactions, 32. (2004) 209-213.

[12] P. Scheldeman, L. Herman, S. Foster, M. Heyndrickx, Bacillus sporothermodurans and other highly heat-resistant spore formers in milk. Journal of Applied Microbiology, 101. (2006) 542-555.

[13] A. D. Warth, Relationship between the heat resistance of spores and the optimum and maximum growth temperatures of Bacillus species. Journal of Bacteriology, 134. (1978) 699-705. 